\title{
IN-SERVICE TEACHERS’ LANGUAGE ATTITUDES IN THE VALENCIAN EDUCATIO- NAL SYSTEM: THE EFFECT OF THE SCHOOL LANGUAGE PROGRAMME AND THE L1
}

\section{LES ACTITUDS LINGÜÍSTIQUES DEL PROFESSORAT EN ACTIU DEL SISTEMA EDUCATIU VALENCIÀ: L'EFECTE DEL MODEL LINGÜÍSTIC I DE LA L1}

\author{
IRENE GUZMÁN-ALCóN \\ Universitat Jaume I \\ iguzman@uji.es \\ LAURA Portolés \\ Universitat Jaume I \\ lportole@uji.es
}

Abstract: The study of teachers' attitudes towards languages has received some attention, as multilingualism has become one of the main educational targets for European school systems (Cenoz 2019; Liyanage \& Tao 2020). Several authors (Lasagabaster 2017; Safont 2007) have claimed that language attitudes may play a crucial role in multilingual education. In the Valencian educational system, existing research has examined both students' language attitudes (Nightingale 20I2, 20I6; Portolés 20I5) and pre-service teachers' language attitudes (Lasagabaster \& Safont 2008; Portolés 20I4; Safont 2007) towards the three teaching languages (i.e., Catalan, Spanish and English). Yet, as far as we know, experienced teachers' attitudes have not been investigated. Thus, the present preliminary study explores $2 \mathrm{I}$ in-service teachers' language attitudes by means of a written questionnaire and a semi-structured interview. In so doing, data were collected in multilingual schools adopting three different school language programmes, namely those of a Catalan-based, a Spanish-based and an English-based language programme. The latter has been

$\left.{ }^{*}\right)$ As members of the LAELA research group at Universitat Jaume I (Castelló, Spain), we would like to acknowledge that this study is part of a research project funded by (a) Ministerio de Ciencia e Innovación (PID2020-117959GB-I00), (b) the Universitat Jaume I (UJI-B2019-23), and (b) Projectes d'Innovació Educativa de la Unitat de Suport Educatiu 3976/21. 
Irene Guzmán-Alcón \& Laura Portolés

In-service teachers' language attitudes in the Valencian educational system:

the effect of the school language programme and the LI

a context that has been omitted in previous research. The findings have confirmed the influence of the language programme on in-service teachers' language attitudes as well as the paramount role of the L1 in the formation of language attitudes. Finally, our findings have pointed out that language attitudes and teaching practices do not always match since some monolingual views are found inside the classroom. Our study concludes that more teacher training is needed on the «Focus on Multilingualism» approach proposed by Cenoz and Gorter (20I3).

Key words: multilingual education, language attitudes, school language programme, L1, in-service teachers

Resum: La investigació sobre les actituds dels professors cap a les llengües ha rebut una certa atenció, en la mesura que el multilingüisme s'ha convertit en un dels principals objectius educatius dels sistemes escolars europeus (Cenoz 2019; Liyanage \& Tao 2020). Diversos autors (Lasagabaster 2017; Safont 2007) han afirmat que les actituds cap a les llengües poden resultar un factor crucial en l'educació multilingüe. En el sistema educatiu valencià, els estudis existents han investigat tant les actituds lingüístiques dels estudiants (Nightingale 2012, 2016; Portolés 2015) com les actituds lingüístiques del futur professorat (Lasagabaster \& Safont 2008; Portolés 20I4; Safont 2007) respecte als tres idiomes d'ensenyament (és a dir, el català, el castellà i l'anglès). No obstant això, les actituds del professorat en actiu no han estat investigades. Per tant, el present estudi preliminar explora les actituds lingüístiques de 2I professores i professors mitjançant un qüestionari escrit i una entrevista semiestructurada. Així doncs, es van recollir dades en tres escoles multilingües on cadascuna implementa un programa lingüístic diferent segons la llengua vehicular predominant: català, castellà o anglès. Aquest darrer no havia estat investigat en recerques anteriors. Els resultats han confirmat la influència del programa lingüístic en les actituds lingüístiques del professorat, com també la funció primordial de la L1 en la formació d'actituds lingüístiques. Finalment, els nostres resultats han assenyalat que les actituds i les pràctiques lingüístiques dins de l'aula no sempre coincideixen, ja que trobem actituds clarament monolingües dins de l'aula. Finalment, el nostre estudi arriba a la conclusió que el professorat necessita una major formació en l'enfocament Focus on Multilingualism proposat per Cenoz \& Gorter (2013).

Paraules clau: educació multilingüe, actituds lingüístiques, programa lingüístic, L1, professors en actiu.

$\cos \cos$

\section{INTRODUCTION}

This small-scale preliminary study is about attitudes towards languages in multilingual instructional contexts. The study of language attitudes has been largely explored in multilingualism research in the last few decades (Cenoz 2009; Lasagabaster 20I7; Safont 2015). However, the role played by those affective factors in the bilingual region of 
Irene Guzmán-Alcón \& Laura Portolés

In-service teachers' language attitudes in the Valencian educational system: the effect of the school language programme and the L1

Valencia has not received the deserved attention until relatively recently, even though several languages coexist in the educational system (i.e., Spanish, Catalan and English). Some studies have already examined the language attitudes towards the three teaching languages in the Valencian school curriculum and their focus has been on students (Nightingale 20I2, 2016; Portolés 2015), pre-service teachers (Lasagabaster \& Safont, 2008; Portolés, 20I4; Safont, 2007) and parents (Safont 20I5). To our knowledge, no previous studies have centred on experienced teachers. Therefore, the purpose of this pilot study is to analyse in-service teachers' language attitudes and investigate the potential effect of the school language programme and the L1 on such attitudes.

The article is structured as follows. Section 2 provides the reader with a brief theoretical framework of language attitudes and describes current studies on language attitudes in the Valencian Community. Special attention is given to the effect of individual variables, such as the school language programme and the L1, on the study of language attitudes. This section closes with the research questions that guide the present study. Subsequently, we introduce the method by describing the participants, the data collection and analysis. In section 4 , we present the results and discuss them by comparing our research to previous findings and drawing some conclusions on whether the language programme and the L1 may have an influence on teachers' language attitudes. Then, we put forward some concluding notes and propose some pedagogical implications. In the last section, the main limitations found are reported and some suggestions for further research are put forward.

\section{THEORETICAL FRAMEWORK}

\section{I MULTILINGUALISM AND LANGUAGE ATTITUDES}

Multilingualism is a global and common phenomenon in our society due to several reasons, such as historical, social, political and economic. The emergence of multilingualism research in the last few decades has increasingly gained importance, although this concept has existed for centuries (Aronin 2019). Multilingualism is a feature of human beings that has been alive since the human species appeared. Barnard (2016: 134) holds that «multilingualism was the norm, and multilingual people were made up of individuals from different linguistic backgrounds, whose groups intermarried and passed on both their genes and their linguistic diversity». Currently, multilingualism has spread in education and become one of the trending topics worldwide (Cenoz 2019; Portolés 2020).

Caplletra 71 (Tardor, 2021), p. 121-146 
Irene Guzmán-Alcón \& Laura Portolés

In-service teachers' language attitudes in the Valencian educational system:

the effect of the school language programme and the L1

Several definitions have been used to refer to multilingual education, although the definition proposed by $\mathrm{Cenoz}$ (2009) has received more attention. The author states that multilingual education refers to «the use of two or more languages in education provided that schools aim at multilingualism and multiliteracy» (Cenoz 2009: I). In the Spanish context, multilingual programmes, which include the teaching of three languages at school, have become increasingly popular in bilingual regions (Cenoz 2009; Lasagabaster \& Ruiz de Zarobe 20IO). These languages are not only used as language subjects, but as vehicles for conveying content subjects such as Maths, Science or Arts and Crafts. Content and Language Integrated Learning (CLIL) has gained popularity in Spain as a strong teaching programme which fosters multilingual education (see Martí 2020 for an updated revision).

Thus, multilingual education entails multiple languages and the affective factors we have towards languages may affect their status and role in the classroom. There is a multitude of affective factors which may play a central role in the process of language learning, although the feelings we have towards a language have been regarded as pivotal in multilingualism research (Baker 1992; Garrett 20IO; Lasagabaster 20I7). These feelings towards a language are referred to as language attitudes. This term has been broadly defined, but the definition provided by Sarnoff has probably gained more consensus. Sarnoff (1970: 279) defines an attitude as «a disposition to react favourably or unfavourably to a class of objects». Accordingly, language attitudes would be the positive or negative feelings attached to a language.

The fundamentals of language attitudes have also been addressed by Garrett (20I0). According to this author (2010), we can distinguish three attitudinal components: cognitive, affective and behavioural. The cognitive component includes the beliefs and perceptions about the language. The affective component involves feelings about the language that may provoke like or dislike. Finally, attitudes are behavioural, since they concern a predisposition to act, which may be in line with a belief or feeling, or not. In this vein, although this construct is a unitary concept, the three components may not coincide.

Baker (1992), one of the most influential researchers in the field of language attitudes, reported that language attitudes are not inherited, but learnt and modified from the environment and experience. Thus, language attitudes may change over time due to the influence of internal and external factors. Lasagabaster (2017) provides a review of the variables that may account for attitudinal differences and highlights that the L1 and the school programme are the most salient predictors on language attitudes. The school and home are places where attitudes are formed, so the importance given to a language may affect the attitudes towards it. In the school context, the 
attitudes held by teachers are pivotal since they are among the agents who create «the relationships between language and power in the classroom and in the curriculum» (de Mejía \& Hélot 20I5: 274). Thus, positive or negative attitudes to languages may be shaped by the prestige and value given to them at school through the language programme implemented. In this sense, the language policy established at school may play a central role in shaping the attitudes of both teachers and students.

After this brief revision of multilingualism and language attitudes, the next section reviews the language attitude studies conducted in the Valencian Community - the context of the current study.

\subsection{STUDIES OF LANGUAGE ATTITUDES IN THE VALENCIAN COMMUNITY}

The study of language attitudes has been widely researched in Spain, especially in those bilingual regions where two or more languages coexist, as is the case of Catalonia (Bernaus \& Gardner 2008; Bernaus et al. 2004; Huguet 2007; Huguet \& Janés 2008; Madariaga, Huguet \& Janés 2016; Newman et al. 2008), the Basque Country (Cenoz \& Valencia 1994; Lasagabaster 2005; Ibarraran et al. 2008; Ipiña \& Sagasta 20I7), the Balearic Islands (Moratinos-Johnston et al. 2019) and Galicia (Loredo Gutiérrez et al. 2007; O'Rourke \& Ramallo 2015). Those studies, to name just a few, have investigated language attitudes towards the majority language (i.e., Spanish), the international foreign language (i.e., English) and the minority language of the region (i.e., Catalan in Catalonia and the Balearic Islands, Basque in the Basque Country and Galician in Galicia). In the context of our study, some previous research has investigated language attitudes towards Spanish, English and Catalan on different age populations. More specifically, they have focused on children (Portolés 2015), teenagers (Nightingale 20I2, 20I6), young adults (Lasagabaster \& Safont 2008; Portolés 20I4; Safont 2007) and adults (Safont 2015).

Portolés (2015) explored 402 pre-schoolers and primary school learners' language attitudes towards the three languages by means of a matched-guise technique and oral interviews. On the whole, global attitudes were very positive among young learners, although there was a decline of favourable attitudes over time. The author also examined the influence of the language programme (Catalan-based and Spanish-based) on children's language attitudes. The findings confirmed the effect of language programme since those students enrolled in Catalan-based programmes reported more positive attitudes towards languages, especially Catalan and English. In contrast, students in Spanish-based schools were more inclined towards Spanish. Similar results were 
Irene Guzmán-Alcón \& Laura Portolés

In-service teachers' language attitudes in the Valencian educational system:

the effect of the school language programme and the L1

reported by Lasagabaster and Safont (2008) pointing out more positive attitudes in those participants who had been schooled in Catalan-based programmes.

Similarly, the studies by Safont (2007) and Portolés (2014) examined the influence of the school language programme and the L1 on 200 and 75 prospective teachers' attitudes respectively. Both authors found that the language programme had an effect on the language attitudes towards Spanish and Catalan, although no significant differences were found in relation to English. In that vein, those students who had been instructed in Catalan reported more positive attitudes towards the three languages than those schooled in Spanish-based programmes. Furthermore, Safont (2007) and Portolés (20I4) concurred on the importance of the role of L1 in language attitudes as participants often showed a preference for their own L1.

Nightingale (2012) analysed the language attitudes of 29 multilingual adolescents in Castelló with a focus on external factors. This author claimed that the English language was particularly sensitive to external factors compared to other languages because of its prestigious status in the sociolinguistic context. The author concluded that media exposure or a stay-abroad period promoted a positive attitude towards English. A second study, carried out by Nightingale (20I6), focused on I 52 secondary school students and investigated the effect of the media exposure on students' language attitudes. This author observed that the status and importance that a language is given in new media platforms, such as social networks and videogames, had a positive impact on attitudes. The findings suggested that students held more positive attitudes towards English and Catalan when they were exposed to those languages in new media platforms.

In the case of the study conducted by Safont (2015), the author focused on Ioo parents of schoolchildren. She investigated their attitudes towards the three contact languages and the results showed that English and Spanish had the most favourable attitudes whereas the attitudes to Catalan were more negative. Safont (2015) also reported that parents who chose Catalan-based schools for their children reported more favourable attitudes to languages, especially Catalan. On the contrary, this was not the case of parents whose school choice was Spanish-based programmes since positive attitudes were found towards English and Spanish, but not towards Catalan.

So far, previous research has examined language attitudes in children (Portolés 20I5), teenagers (Nightingale 20I2), pre-service teachers' attitudes (Portolés 20I4; Safont 2007) and parents (Safont 2015). The findings derived from those studies have also confirmed the paramount effect of individual variables, such as the language programme, the L1 and out-of-school factors. However, to the best of our knowledge, no studies have explored the language attitudes of experienced teachers working in 
the Valencian educational system. Furthermore, regarding the language programme, previous studies have analysed Spanish and Catalan-based programmes while Englishbased programmes (i.e., schools where English is the main language of instruction) have not still received attention.

Taking into account those research gaps found, the present pilot study aims at adding more insights into language attitudes studies by investigating the effect of the school language programme and the L1 on in-service teachers' attitudes towards the three contact languages. Accordingly, the following research questions have been formulated to guide the study:

Research Question I: Does the school language programme affect teachers' attitudes towards languages?

Research Question II: Do in-service teachers' language attitudes differ depending on the L1?

\section{METHOD}

\section{I PARTICIPANTS}

The sample consisted of a total of 2I primary school teachers in the province of Castelló, Spain. The age range of the sample was from 26 to 68 years old $(M=38.3)$ and the gender distribution was $77.3 \%$ female $(n=17)$ and $22.7 \%$ male $(n=4)$. Regarding their L1, 24\% $(n=5)$ participants had English, 38\% $(n=8)$ had Spanish and 38\% $(n=8)$ had Catalan. All participants held a degree in Teacher Training and had a minimum teaching experience of five years in their respective schools.

The participants were selected from multilingual schools adopting three different language programmes, which vary regarding exposure to languages. We may find Spanish-based, Catalan-based and English-based schools. In so that, $38 \%$ of the sample $(n=8)$ worked in an English-based school language programme, $33 \%$ of them $(n=7)$ followed Catalan-based school language programme whereas the other $29 \%(n=6)$ of the participants followed a Spanish-based school language programme.

The school adopting the English-based language programme is a British school where English is the main language of tuition. This centre is one of the private coeducational British schools in the Spanish region of Castelló. The vast majority of pupils (97\%) are Spanish. Regarding the distribution of teaching languages, English is the main teaching language in all the subjects, except for the Spanish and Valencian subjects. However, Spanish is the main language used among the pupils out of class. 
Irene Guzmán-Alcón \& Laura Portolés

In-service teachers' language attitudes in the Valencian educational system:

the effect of the school language programme and the L1

The Catalan-based school is located in the north-eastern part of the city of Castelló and adopts a programme, known as Programa Plurilingüe en Valencià, in which the main vehicular language is Catalan. Thus, most subjects are taught in Catalan, except for some subjects which are instructed in Spanish. Recently, they have also started to teach subjects in English using a CLIL approach. The hours of this approach are gradually increased according to the students' academic year in two subjects: Physical Education and Science.

The Spanish-based school follows the Spanish-based programme or Programa Plurinlingüe en Castellà. The main language of tuition is Spanish and other languages are employed to a lesser extent. Similar to the Catalan-based programme, English is the vehicular language in Physical Education, Science, and Arts and Crafts. The number of hours of CLIL also differ according to students' academic level. As follows, Table I summarises the main characteristics of the sample participating in the current study.

Table I. Characteristics of the sample

\begin{tabular}{|c|c|c|c|}
\hline \multicolumn{2}{|c|}{} & Participants & Percentage \\
\hline \multirow{3}{*}{ Gender } & Female & 17 & $77.3 \%$ \\
\cline { 2 - 4 } & Male & 4 & $22.7 \%$ \\
\hline \multirow{3}{*}{ L1 } & Catalan L1 & 8 & $38 \%$ \\
\cline { 2 - 4 } & Spanish L1 & 8 & $38 \%$ \\
\cline { 2 - 4 } & English L1 & 5 & $24 \%$ \\
\hline \multirow{3}{*}{ Language Programme } & Catalan-Based Programme & 7 & $33 \%$ \\
\cline { 2 - 4 } & Spanish-Based Programme & 6 & $29 \%$ \\
\cline { 2 - 4 } & English-Based Programme & 8 & $38 \%$ \\
\hline
\end{tabular}

\subsection{DATA COLLECTION AND ANALYSIS}

A written questionnaire, based on Lasagabaster and Huguet (2007), was used for the purpose of our study to examine in-service language attitudes towards the three teaching languages (see Appendix I).

The instrument was structured in two main sections. The first section gathered demographic information such as gender, L1 and age. The second section targeted participants' attitudes towards the three teaching languages of the Valencian Com- 
munity: Catalan, Spanish and English. The language attitudes items were analysed by means of a five-point Likert scale. The Io items of the questionnaire contained a number of statements designed to gather attitudinal data in each of the three languages in different contexts: social, educational and personal. Next, we present an example of the statements regarding the Catalan language.

I. I like listening to Catalan language

2. Catalan should be taught in every school in the Valencian Community

3. I like to speak Catalan

4. Catalan is an easy language to learn

5. Catalan is one of the most useful languages in the world

6. I would rather have classes in Catalan

7. Catalan language enriches my cultural background

8. I would not mind marrying someone who only spoke Catalan

9. It is worth it to learn Catalan

Io. If I had children, I would like them to learn Catalan

The statements I, 3, 8 and Io allowed us to assess the respondents' individual preference and comfort when using the language in different settings whether it might be inside or outside school. In contrast, statements 2, 4 and 6 dealt with teachers' attitudes towards the use of the language as a teaching language at school. Finally, statements 5, 7 and 9 asked for their views about the social status of the language. Thus, the questionnaire included statements about individual, educational and social use of languages.

The questionnaire was administered to the teachers participating in the study who had thirty minutes to complete it. After completing the questionnaire, short semi-structured oral interviews were conducted with the participants (see Appendix II). Those interviews were audio-recorded and transcribed. The aim of the interviews was to complement and expand the quantitative data.

Data obtained in the questionnaire were codified and analysed using the Excel programme.

\section{RESULTS AND DISCUSSION}

With reference to the first research question, we investigated whether the English-based language programme, the Spanish-based language programme and the Catalan-based language programme may influence teachers' attitudes towards 
Irene Guzmán-Alcón \& Laura Portolés

In-service teachers' language attitudes in the Valencian educational system:

the effect of the school language programme and the LI

the three languages of instruction (English, Catalan and Spanish). The results are illustrated in the figures below.

Figure I depicts the main findings derived from the questionnaire regarding the effect of the language programme on teachers' attitudes towards English. As illustrated, the teachers working in the English-based language programme denoted the most favourable attitudes towards English $(M=9 \mathrm{I} .5)$, followed by those in the Catalan-based language programme $(M=89.75)$, and the least positive attitudes were held by those teachers in the Spanish-based school $(M=52.4)$.

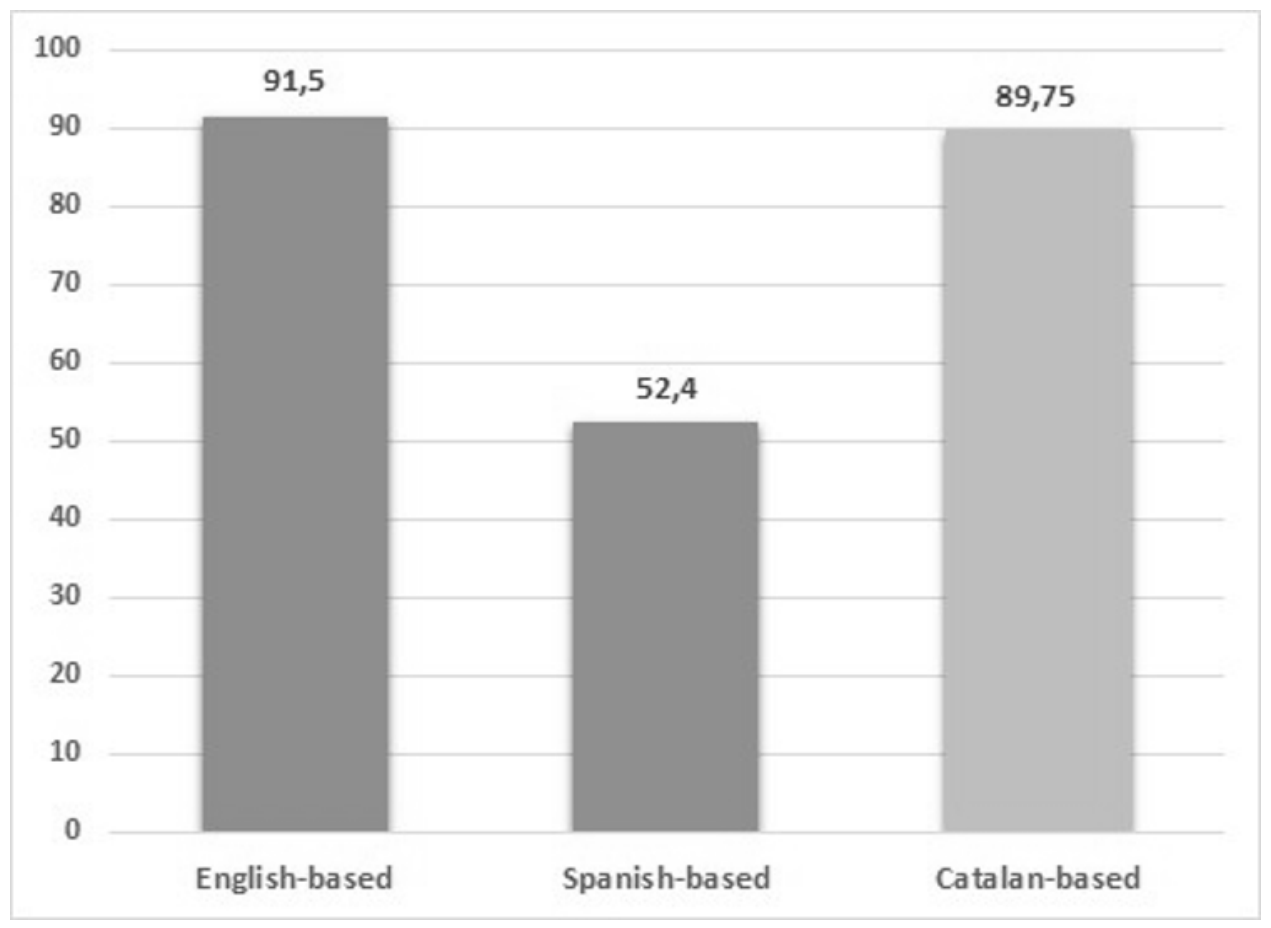

Figure I. The effect of the school language programme on teachers' attitudes towards English

Thus, both teachers from the English-based and the Catalan-based schools reported very positive attitudes towards English, whereas the teachers from the Spanish-based school did not show such a positive attitude. Furthermore, it is worth mentioning that teachers' attitudes from the Catalan-based and English-based language programmes were positive, both at the level of individual and educational use. This nuance is particularly apparent for teachers from the Spanish-based school as they 
did not have a positive attitude towards English as an individual preference $(M=38.2)$, but still agreed on using English as a vehicular language at school (M=6I.3). Those findings suggest that teachers from Spanish-based schools agreed on the importance of English in educational contexts but were less enthusiastic in individual language use. In particular, one possible explanation is that teachers working at the Spanishbased school were required to obtain a $\mathrm{B}_{2}$ level of English, which may have triggered a rejection towards the language. On the other hand, teachers from the Catalan and English based-school did not have to comply with an English level certificate and consequently did not perceive the English language negatively.

In relation to participants' attitudes towards the Catalan language, those practitioners in the Catalan-based school showed very favourable attitudes $(M=88.75)$. In contrast, a predominance of neutral attitudes were found in the Spanish-based school $(M=48.8)$ and the English-based school $(M=4 \mathrm{I} .5)$, as illustrated in Figure 2 below.

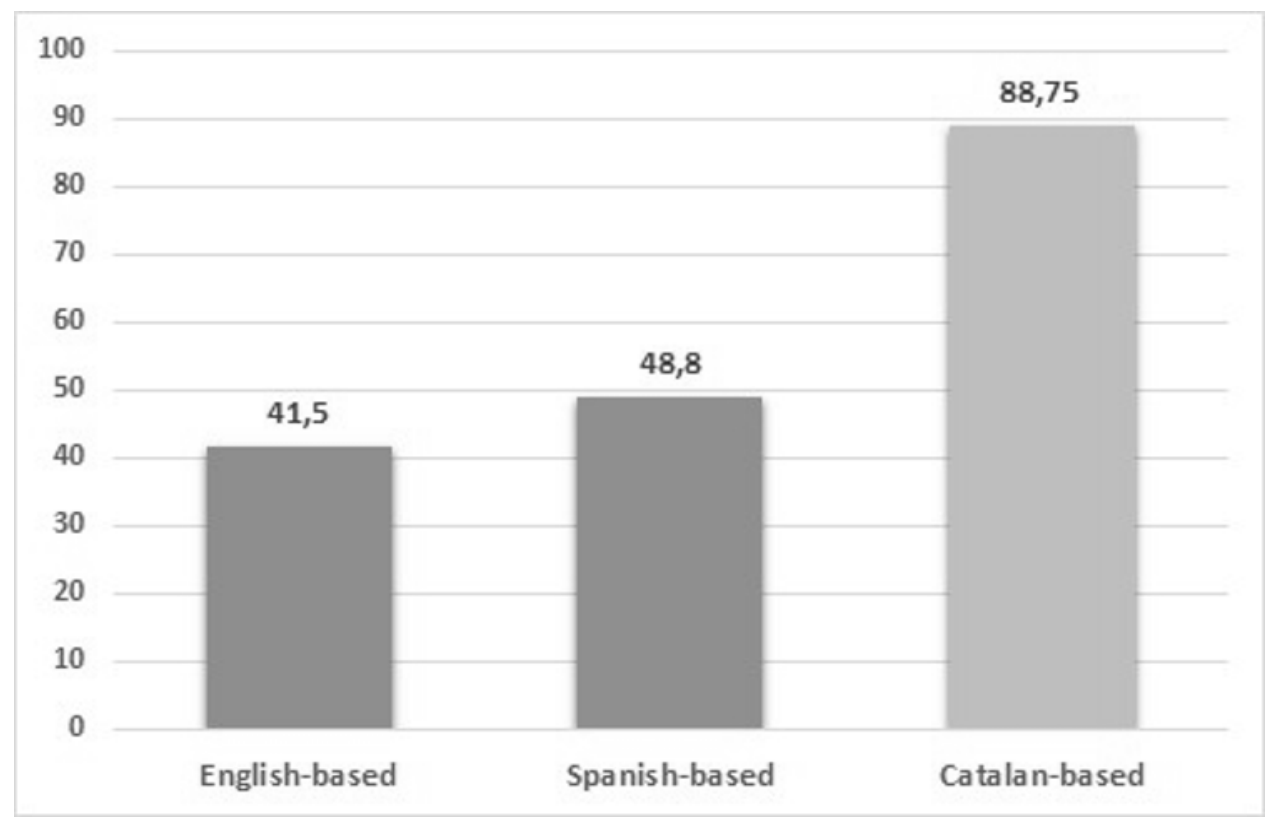

Figure 2. The effect of the school language programme on teachers' attitudes towards Catalan

The analysis of teachers' attitudes towards Catalan in the three educational contexts reported significant differences. While teachers in the Catalan-based language programme expressed overall favourable attitudes towards the use of Catalan in edu- 
Irene Guzmán-Alcón \& Laura Portolés

In-service teachers' language attitudes in the Valencian educational system:

the effect of the school language programme and the LI

cation, participants working in the other instructional settings held a rather negative attitude. In spite of this, participants in the three educational contexts indicated a favourable attitude towards Catalan as language for identification and culture. They reported positive attitudes towards the following items: it is worth learning Catalan, they would like their children to speak Catalan, understand Catalan as part of their culture, and they would not mind their partners being a Catalan speaker. The agreement rate for these four statements was over $65 \%$ in the three school language programmes. In other words, our respondents held a positive attitude towards individual language use, but not towards its social and educational use.

Concerning participants' attitudes towards the Spanish language, the respondents in the three educational contexts reported a very positive attitude towards the Spanish language. As seen in Figure 3 below, the practitioners in the Spanish-based school $(M=90.4)$ denoted the most favourable attitudes, followed by those in the Englishbased school $(M=79.5)$, and finally, those in the Catalan-based school $(M=79.0)$. This attitudinal pattern is much more positive and homogeneous compared to the attitudes towards the Catalan or the English language.

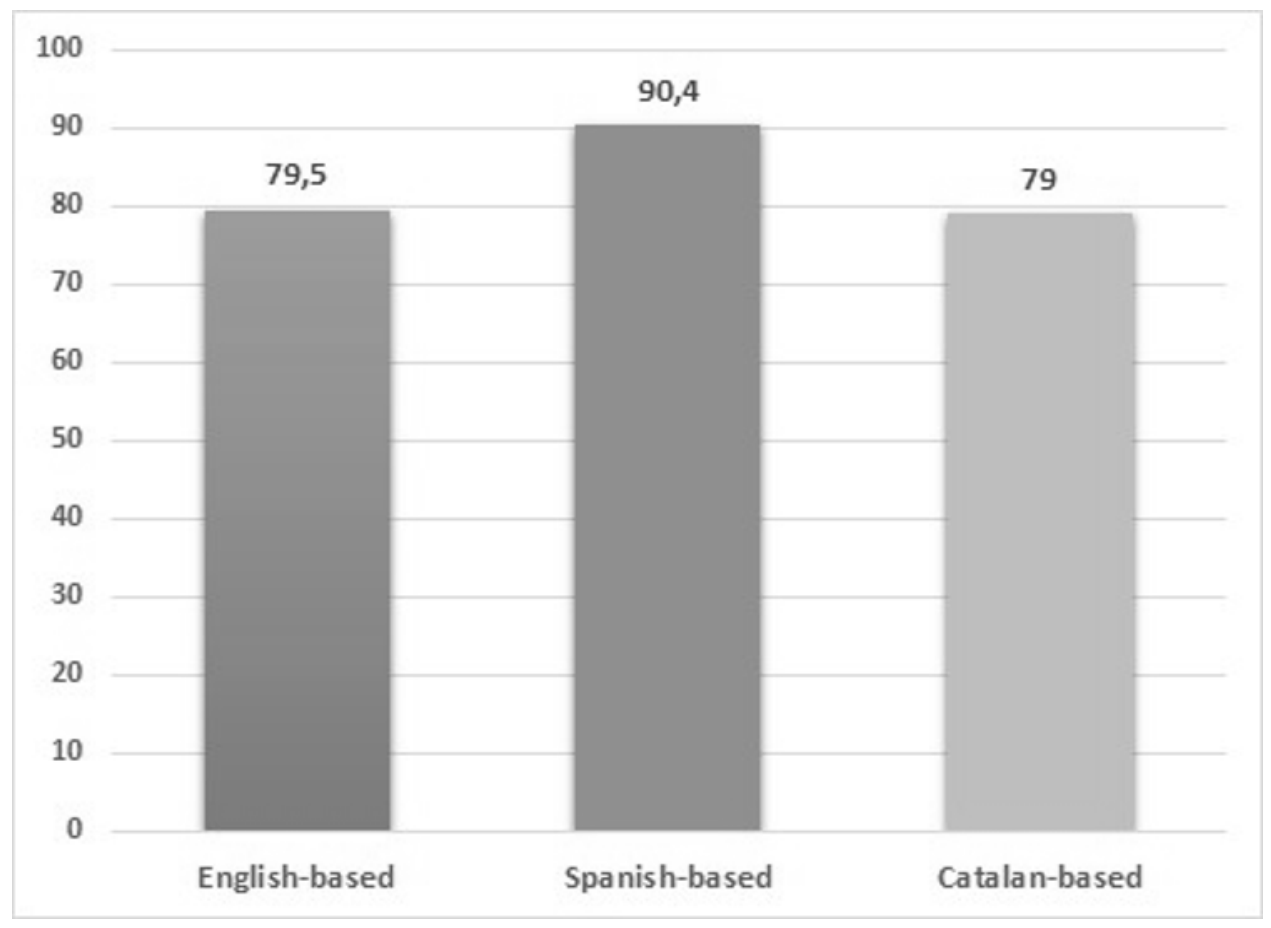

Figure 3.The effect of the school language programme on teachers' attitudes towards Spanish 
In general, our findings showed that teachers from the Spanish-based model reported the most positive attitudes in all the items. English and Catalan-based school teachers also reported a very positive attitude in all items, except for statement 5 which refers to the utility of a language in the world. Spanish teachers held a very positive attitude $(M=79.5)$, whereas English and Catalan teachers questioned that statement with more reserved answers ( $M=60$ and $M=33$ respectively). The fact teachers in the Spanish-based school refer to the Spanish language as the most useful language can be explained as they might see the English language as a threat and they want to keep their teaching language predominant. Regarding teachers from the Catalan-based programme, their negative attitude $(M=33)$ towards the supremacy of Spanish may be explained considering the sociolinguistic context in the Valencian Community. Indeed, Catalan being a minority language, teachers from the Catalan-based programme may feel the need to protect their language and give its place at the school context.

In order to further examine teachers' attitudes and the effect of the school language programme, we would like to add some of the responses obtained in the semi-structured interviews, which reinforce and complement our quantitative findings. Generally speaking, teachers reported feeling more comfortable using the main language of the school they were working in. This issue can be illustrated in some of the teachers' responses to the question «Do you allow your students to use another language in class? If so, what is the purpose? " (see Table 2 below).

Table 2. Teachers' attitudes in each language programme. Responses to question one.

\begin{tabular}{|l|l|l|}
\hline \multicolumn{1}{|c|}{ English-based school } & \multicolumn{1}{c|}{ Catalan-based school } & \multicolumn{1}{c|}{ Spanish-based school } \\
\hline $\begin{array}{l}\text { Teacher 1: «No, only in } \\
\text { English, this is a British } \\
\text { school» }\end{array}$ & $\begin{array}{l}\text { Teacher 4: «En valencià, } \\
\text { volem que a l'escola es parle } \\
\text { en valencià» }\end{array}$ & $\begin{array}{l}\text { Teacher 7: «Castellano, } \\
\text { intentamos que los niños } \\
\text { hablen en castellano lo } \\
\text { máximo que podamos» }\end{array}$ \\
\hline $\begin{array}{l}\text { Teacher 2: «Mainly English, } \\
\text { sometimes Spanish but we } \\
\text { always try to use the English } \\
\text { language» }\end{array}$ & $\begin{array}{l}\text { Teacher 5: «No. Parlem en } \\
\text { valencià» }\end{array}$ & $\begin{array}{l}\text { Teacher 8: «A veces, los } \\
\text { niños hablan en valenciano } \\
\text { pero hacemos que no lo } \\
\text { entendemos hasta que no } \\
\text { hablan en castellano, ya que es } \\
\text { lo que queremos enseñarles» }\end{array}$ \\
\hline $\begin{array}{l}\text { Teacher 3: «English without } \\
\text { any doubt» }\end{array}$ & $\begin{array}{l}\text { Teacher 6: «Parlen castellà } \\
\text { però insistim en el fet que } \\
\text { utilitzen la nostra llengua» }\end{array}$ & $\begin{array}{l}\text { Teacher 9: «Todos hablan en } \\
\text { castellano» }\end{array}$ \\
\hline
\end{tabular}


Irene Guzmán-Alcón \& Laura Portolés

In-service teachers' language attitudes in the Valencian educational system:

the effect of the school language programme and the L1

The comments above show that teachers mainly use the predominant language of the school. Most of the teachers favoured the main language of each programme and were sceptical towards the use of other languages inside the classroom. Their actual behaviour in the classroom is monolingual-biased, although all the teachers in the three schools reported that multilingual education was important in their school. This mismatch can be observed looking at teachers' answers to the question «Is multilingual education important in your school? ». Some comments are reported below in Table 3:

Table 3. Teachers' attitudes in each language programme. Responses to question two.

\begin{tabular}{|l|l|l|}
\hline \multicolumn{1}{|c|}{ English-based school } & \multicolumn{1}{|c|}{ Catalan-based school } & \multicolumn{1}{c|}{ Spanish-based school } \\
\hline $\begin{array}{l}\text { Teacher 1: «Yes absolutely, } \\
\text { it’s the essence of the whole } \\
\text { school» }\end{array}$ & $\begin{array}{l}\text { Teacher 4: «Sí, perquè oferim } \\
\text { valencià, castellà, anglès i } \\
\text { francès» }\end{array}$ & $\begin{array}{l}\text { Teacher 7: «Muchísimo, } \\
\text { cuando más idiomas mejor, } \\
\text { esta escuela ofrece hasta } \\
\text { alemán» }\end{array}$ \\
\hline $\begin{array}{l}\text { Teacher 2: «Very important. } \\
\text { Multilingualism is a key for } \\
\text { the future» }\end{array}$ & $\begin{array}{l}\text { Teacher 5: «Sí, a l'escola es } \\
\text { parla valencià, castellà, francès } \\
\text { i anglès» }\end{array}$ & $\begin{array}{l}\text { Teacher 8: «Bastante, la } \\
\text { educación multilingüe abre la } \\
\text { mente a los niños y les empuja } \\
\text { al futuro» }\end{array}$ \\
\hline $\begin{array}{l}\text { Teacher 3: «Of course we are a } \\
\text { multilingual school» }\end{array}$ & $\begin{array}{l}\text { Teacher 6: «Clar, estem dins } \\
\text { dels programa plurilingüe» }\end{array}$ & $\begin{array}{l}\text { Teacher 9: «Si, los niños } \\
\text { tienen posibilidad de estudiar } \\
\text { varias lenguas» }\end{array}$ \\
\hline
\end{tabular}

As seen in Table 3 above, most of the teachers' responses show that they were in favour of multilingualism. In fact, I9 of 2I reported that multilingualism was very beneficial. However, as observed in the responses from teachers 4, 5 and 7 , the concept multilingual education is reduced to the number of languages offered at school. Although they reported to have positive attitudes to languages and welcomed linguistically diverse classrooms, their actual knowledge about multilingual pedagogies is very weak, as occurred in the study conducted by Schroedler and Fisher (2020). Despite their positive attitudes and predisposition towards multilingualism at first sight, their actual teaching practices are still monolingual in orientation. Therefore, their beliefs are not consistent with the behaviour. These findings may provide evidence of the mismatch between the cognitive and behavioural component in the attitudinal construct, as suggested by Garrett (2010).

Taking into consideration our results, we may confirm the effect of the school language programme on teachers' language attitudes. These findings are in line with previous research conducted in the Valencian region at the university (Lasagabaster \& Safont 2008; Portolés 20I4; Safont 2007) and the school context (Portolés 2015), 
pointing out that the language programme has an influence on the respondents' attitudes towards languages, especially Catalan. We have found that the participants working in the Catalan-based school show the most positive attitudes towards all three languages, while the teachers in the Spanish and English-based schools hold some negative attitudes towards Catalan when it comes to use the minority language for social and educational purposes. With reference to Spanish, favourable attitudes towards Spanish dominate in the three language programmes. In the case of English, we have observed that practitioners in the Spanish-based program hold a neutral attitude towards the foreign language, although they do understand its active role at the school context.

Moving on to the second research question, we explored whether teachers' language attitudes towards English, Catalan and Spanish differ in accordance with their L1.

Figure 4 provides us with information on the impact of the L1 on teachers' language attitudes towards English. As illustrated in Figure 4, the participants whose L1 is English indicated a very positive attitude towards English $(M=96.8)$. Similarly, those with $\mathrm{L} 1=$ Spanish and $\mathrm{L} 1=$ Catalan also held a positive attitude towards this language ( $M=72.25$ and $M=72.25$ respectively). In general, no negative attitude was observed towards English, regardless of the participants' L1. In line with previous studies in the Valencian region, like Portolés (2014) or Nightingale (2OI2), these findings may be explained due to the prestige and powerful status of English in our globalized society.

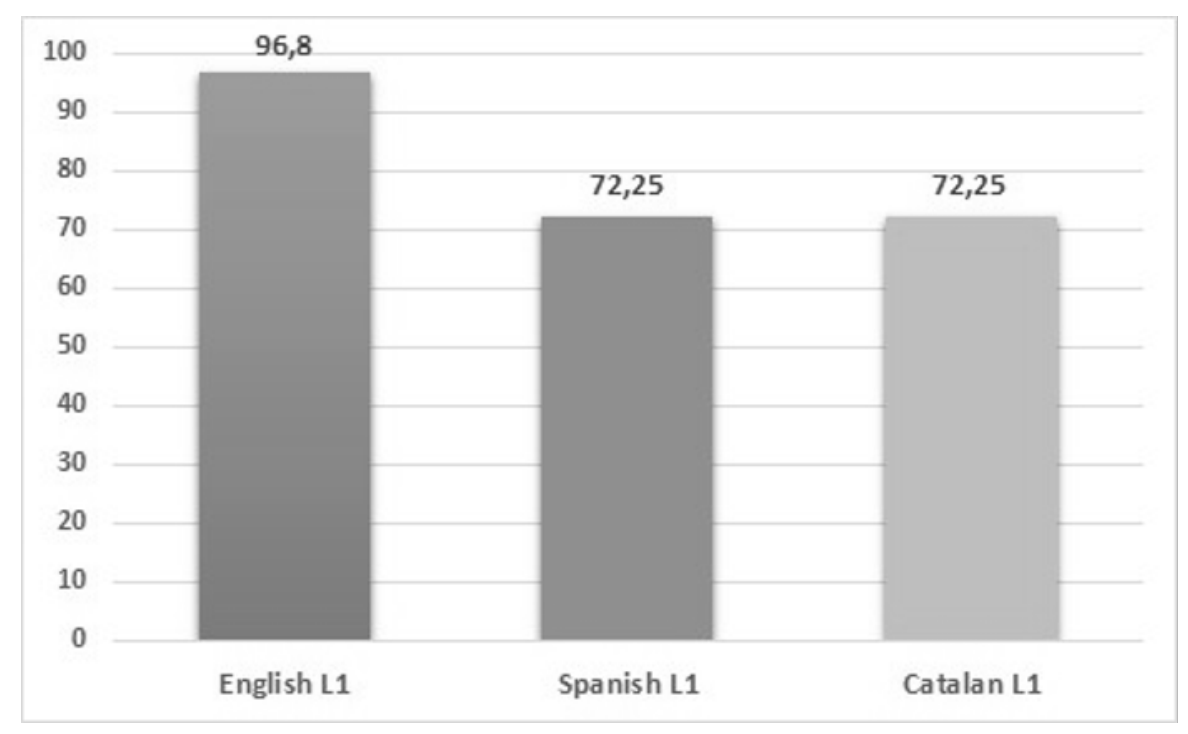

Figure 4. The effect of the L1 on teachers' attitudes towards English 
Irene GuZmán-Alcón \& Laura Portolés

In-service teachers' language attitudes in the Valencian educational system:

the effect of the school language programme and the LI

In relation to participants' attitudes towards Catalan, Figure 5 describes that those participants whose $\mathrm{L} 1$ was Catalan demonstrated very positive attitudes towards their own language $(M=84.25)$. In contrast, participants whose L1 was Spanish held neutral attitudes $(M=54.25)$, while those whose L1 was English reported rather negative attitudes towards the minority language $(M=35.6)$.

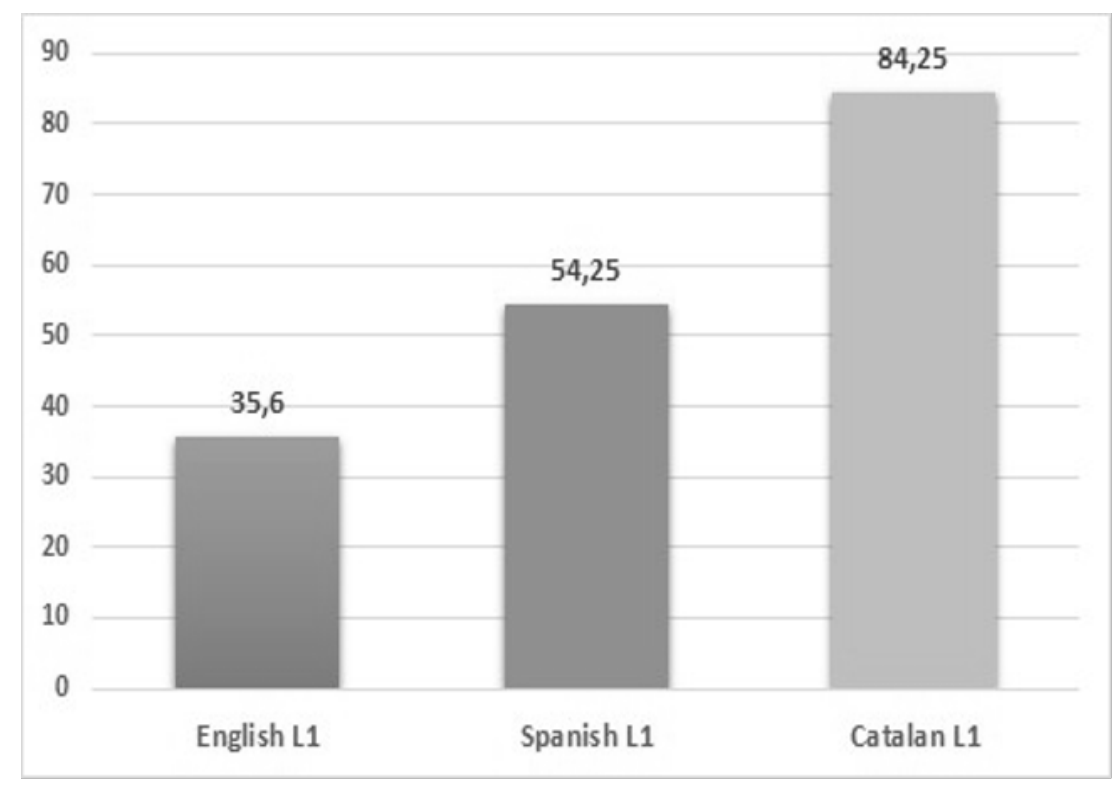

Figure 5. The effect of the L1 on teachers' attitudes towards Catalan

More specifically, English-native speakers denoted unfavourable attitudes towards the individual, educational and social use of the minority language. In the case of participants whose L1 was Spanish, they also reported a negative attitude towards the social and educational use of the language. These results suggest that those practitioners do not recognize the role of the minority language in society or in education, although they do not mind using the minority language in their daily life for individual purposes. 


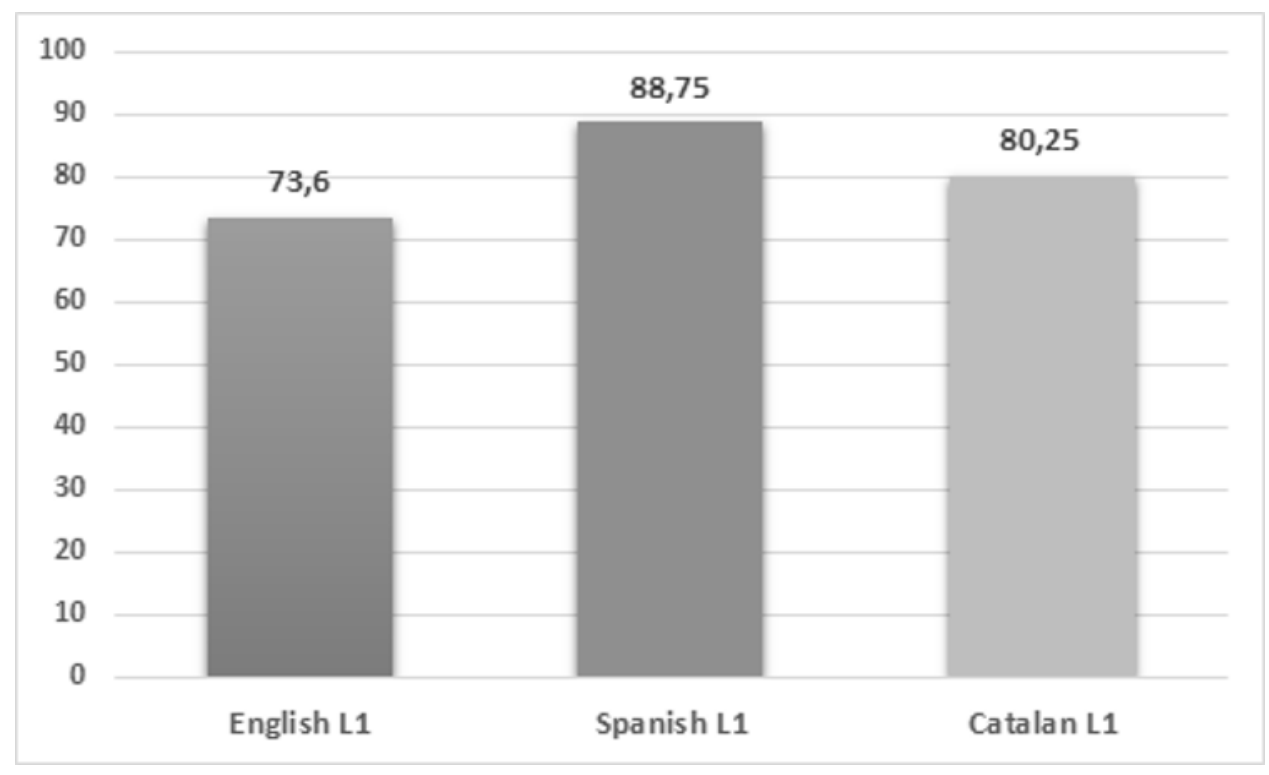

Figure 6. The effect of the L1 on teachers' attitudes toward Spanish

The participants' attitudes towards Spanish are illustrated in Figure 6 above. All the participants held very favourable attitudes towards Spanish irrespective of their L1. Participants with $\mathrm{L} 1=$ Spanish reported the highest positive attitudes towards Spanish $(M=88.75)$, followed by those whose L1 was Catalan $(M=80.25)$ and finally, the least favourable attitudes were held by those with $\mathrm{L} 1=$ English $(M=73.6)$. These results are similar to the results of research question I in which the powerful sociolinguistic status of Spanish as a majority language may exert some positive influence on participants' attitudes towards Spanish regardless of the language programme or the L1.

The findings related to research question II have confirmed that teachers' language attitudes differ according to their L1. Our quantitative findings are complemented from data obtained in the semi-structured interviews since teachers reported feeling more comfortable using their preferred language (i.e., their L1). Indeed, teachers expressed their preference towards their own language when they were asked the following question: «Are you more comfortable when you speak English, Catalan or Spanish? " Responses from the teachers can be found in Table 4 below: 
Irene Guzmán-Alcón \& Laura Portolés

In-service teachers' language attitudes in the Valencian educational system:

the effect of the school language programme and the L1

Table 4. Teachers' attitudes in each L1. Responses to question three.

\begin{tabular}{|c|c|c|}
\hline Teachers with L1=English & Teachers with L1=Catalan & Teachers with $L 1=$ Spanish \\
\hline $\begin{array}{c}\text { Teacher 1: «In English, this is } \\
\text { my language» }\end{array}$ & $\begin{array}{c}\text { Teacher 5: «En valencià, en } \\
\text { anglès segur que no. No tinc } \\
\text { ni idea» }\end{array}$ & $\begin{array}{c}\text { Teacher 9: «Castellano porque } \\
\text { es mi L1» }\end{array}$ \\
\hline Teacher 2: «English, no doubt» & $\begin{array}{l}\text { Teacher 6: «En valencià, } \\
\text { sempre parle en valencià» }\end{array}$ & $\begin{array}{c}\text { Teacher 10: «Castellano es la } \\
\text { lengua del país. Es la que se } \\
\text { habla aquí» }\end{array}$ \\
\hline $\begin{array}{l}\text { Teacher 3: «English, I like } \\
\text { speaking English» }\end{array}$ & Teacher 7: «Valencià i anglès» & $\begin{array}{l}\text { Teacher 11: «En valenciano } \\
\text { no, y tampoco ayuda a los } \\
\text { alumnos» }\end{array}$ \\
\hline $\begin{array}{l}\text { Teacher 4: «English is better } \\
\text { for students' future» }\end{array}$ & $\begin{array}{l}\text { Teacher 8: «No hauríem de } \\
\text { tindre preferència, però cal fer } \\
\text { servir la nostra llengua» }\end{array}$ & $\begin{array}{c}\text { Teacher 12: «Castellano y } \\
\text { también inglés, aunque me } \\
\text { cuesta más» }\end{array}$ \\
\hline
\end{tabular}

As illustrated in those examples above, the preference for one's L1 has been repeated quite frequently as expected. In line with the studies conducted by Safont (2007) and Portolés (2014, 20I5), attitudes towards one's L1 often tend to be positive regardless of the age population. Those findings reflect the individual's desire to be part of their language community. Yet, those results may seem monolingual in orientation, as depicted in example number ten. That teacher preferred Spanish because it is the dominant and majority language spoken in her country. This may be perceived as a clear example of a monolingual viewpoint, as is also the case of example II in which that teacher does not accept the Catalan language.

Taking into account the results derived from the second research question, we can confirm the impact of the L1 on in-service teachers' language attitudes. Indeed, the most evident result that we have confirmed is that participants always tend to have a more positive attitude towards their own L1, as suggested by Safont (2007) and Portolés (2014, 2015). Nevertheless, external factors such as the sociolinguistic status of a language have proven to be significant contributors in making a language more or less appealing to in-service teachers. Correspondingly, in line with previous studies (Nightingale 20I2, 20I6), our results have shown that the status of the language also played a paramount role in developing certain attitudes. This fact is confirmed by the fact that participants denoted positive attitude towards Spanish and English regardless of the L1. In contrast, English and Spanish native-speakers showed negative attitudes towards the local language. 
Irene Guzmán-Alcón \& Laura Portolés

In-service teachers' language attitudes in the Valencian educational system: the effect of the school language programme and the L1

To sum up this section, the present preliminary study focused on multilingual in-service teachers has found the following attitudinal pattern towards the three teaching languages in the Valencian region. On the whole, their attitudes towards Spanish are the most positive, followed by English and the least favourable attitudes are denoted towards Catalan. The effect of the language programme and the L1 has also been noted. Our study has found predominantly positive attitudes towards English and Spanish whereas attitudes towards Catalan seem to be more sensitive to the language programme and the L1. This fact may be explained through the power of each language. As occurred in previous studies (Nightingale 20I2; Portolés 2015), our findings may be influenced by the sociolinguistic status of each language, i.e., the value and prestige attached to the language in a given context. From a global perspective, positive attitudes towards English can be explained by the prestige of English and its increasing presence in educational and social spheres. In addition, positive attitudes towards Spanish may be explained by the overruling power of Spanish outside the school as the national and dominant language of Spain. In contrast, the lack of prestige of Catalan as a minority language explains why attitudes towards the Catalan language are more sensitive to external factors such as the language programme or personal data, like the L1.

\section{CONCLUDING REMARKS AND SOME PEDAGOGICAL IMPLICATIONS}

This small-scale preliminary study has contributed to the corpus of language attitude studies by examining teachers' language attitudes towards Spanish, Catalan and English in the Valencian Community, a multilingual setting which has been under investigated. Previous studies have mainly focused on students from different stages of education: preschool and primary school (Portolés 20I5), secondary school (Nightingale 20I2, 2016) and university (Lasagabaster \& Safont 2008; Safont 2007; Portolés 20I4). However, as far as we know, no research has been done with in-service teachers working at an English-based language programme and including teachers with $\mathrm{L} 1=$ English. Our findings have proven the effect of the language programme and the L1 on teachers' language attitudes. Generally speaking, our participants have demonstrated positive attitudes towards Spanish and English across language programmes and L1s. However, in-service teachers' language attitudes towards Catalan were less favourable and clearly determined by external (i.e., language programme) and internal factors (i.e., L1), as occurred in previous research (Portolés 20I4, 2015; Safont 2007, 2015). We have also found that in-service teachers' attitudes held some monolingual views when facing the multilingual classroom. Even though they were

Caplletra 71 (Tardor, 2021), p. 121-146 
Irene Guzmán-Alcón \& Laura Portolés

In-service teachers' language attitudes in the Valencian educational system:

the effect of the school language programme and the L1

supposed to be in favour of multilingualism, their reported teaching practices were quite monolingual-based since only the target languages were permitted inside the classroom and they often expressed preference for dominant languages, such as Spanish and English.

Some pedagogical implications may be derived from this study which are worth considering. First and foremost, there is a need for training teachers on how to apply a multilingual educational approach in the classroom (Liyanage \& Tao 2020; Otwinowska 20I7). One possibility to avoid the divorce between teachers' positive attitudes towards multilingual education and monolingual classroom practices could be to encourage teachers to explore «focus on multilingualism» approach (Cenoz \& Gorter 20II, 20I3). In so doing, teachers could work with an integrated language curriculum and a holistic view of language learning, as proposed by several scholars (Cenoz 2019; García \& Flores 20I2; Leonet, Cenoz \& Gorter 2017; Portolés \& Martí 2020). Secondly, the implementation of these multilingual pedagogies may change attitudes to languages and create some multilingual sensibilities and awareness to home languages, whether they are local, national or international (Juan-Garau 2020). Thirdly, teachers' positive attitudinal change may affect students' attitudes to languages. As reported by Portolés (2015: 90), «young learners' attitudes are shaped by the classroom and the teacher plays a paramount role in their formation». Last but not least, language policies that privilege the minority language are recommended as Catalan-based schools may counterbalance the low-prestige that Catalan has outside the school community.

\section{LIMITATIONS AND SUGGESTIONS FOR FURTHER RESEARCH}

Since this is a preliminary study, we are completely aware of two main limitations. First and foremost, the number of participants is very limited so our results are not generalizable and reliable. The second limitation is the basic analysis of our preliminary data since statistical procedures were not employed. Thus, taking into account these two major limitations, further research that includes a larger sample is needed as well as a deeper data analysis using statistical packages, such as the SPSS programme.

Irene GuZMÁN-Alcón

Universitat Jaume I iguzman@uji.es

ORCID oooo-0002-2708-II84 


\section{BIBLIOGRAPHIC REFERENCES}

Aronin, L. (2019) «Lecture I: What is multilingualism? », in D. Singleton \& L. Aronin (eds.), Twelve lectures in Multilingualism, Bristol, Multilingual Matters, p. 3-34. [DOI: 10.21832/9781788922074.]

Baker, C. (1992) Attitudes and language, Bristol, Multilingual Matters.

Barnard, A. (2016) Language in Prehistory, Cambridge, Cambridge University Press. [DOI: IO.IOI7/CBO9781139644563.]

Bernaus, M., A-M. Masgoret, R. C. Gardner \& E. Reyes (2004) «Motivation and attitudes towards learning languages in multicultural classrooms», International Journal of Multilingualism, I(2), p. 75-89. [DOI: 10.I080/14790710408668180.]

Bernaus, M. \& R. C. Gardner (2008) «Teacher motivation strategies, student perceptions, student motivation, and English achievement», The Modern Language Journal, 92(3), p. 387-4OI. [DOI: I0.IIII/j.I540-4781.2008.00753.x.]

Cenoz, J. (2009) Towards multilingual education: Basque educational research from an international perspective, Bristol, Multilingual Matters.

- (2019) "Translanguaging pedagogies and English as a lingua franca», Language Teaching, 52 (I), p. 7I-85. [DOI: I0.1017/So26I444817000246.]

Cenoz, J. \& D. Gorter (20II) «Focus on Multilingualism: A Study of Trilingual Writing», The Modern Language Journal, 95(3), p. 356-369. [DOI: I0.IIII/j.I540478I.20II.0I206.x.]

- (2013) «Focus on multilingualism as an approach in educational contexts», in A. Creese \& A. Blackledge (eds.), Heteroglossia as practice and pedagogy, Berlín, Springer, p. 239-254.

- (2017) «Translanguaging as a pedagogical tool in multilingual education», in J. Cenoz, D. Gorter \& S. May (eds.), Language Awareness and Multilingualism, Cham, Springer, p. 309-32I.

Cenoz, J. \& J. F. Valencia (1994) «Additive trilingualism: Evidence from the Basque country», Applied Psycholinguistics, I5(2), p. 195-207.

De Mejía, A. M., \& C. Hélot (20I5) «Teacher education and support», in W. E. Wright, S. Boun, \& O. Garcia (eds.), Handbook of bilingual \& multilingual education, Malden, Wiley-Blackwell, p. 270-28I. 
Irene Guzmán-Alcón \& Laura Portolés

In-service teachers' language attitudes in the Valencian educational system:

the effect of the school language programme and the L1

García, O. \& N. Flores (2OI2) «Multilingual pedagogies», in M. Martin-Jones, A. Blackledge \& A. Creese (eds.), The Routledge handbook of multilingualism, Abingdon, Regne Unit, Routledge, p. 232-246.

Garrett, P. (20I0) Attitudes to Language, Cambridge, Cambridge University Press. [DOI: 10.1017/CBO9780511844713.]

Huguet, A. (2006) «Attitudes and motivation versus language achievement in cross-linguistic settings. What is cause and what effect? ", Journal of Multilingual and Multicultural Development, 27(5), p. 413-429.

- (2007) «Language Use and Language Attitudes in Catalonia», in D. Lasagabaster \& A. Huguet (eds.), Multilingualism in European Bilingual Contexts: Language Use and Attitudes, Clevedon, Multilingual Matters, p. 17-40.

Huguet, A. \& J. Janés (2008) «Mother Tongue as a Determining Variable in Language Attitudes. The Case of Immigrant Latin American Students in Spain", Language and Intercultural Communication, 8(4), p. 246-26o. [DOI: https://doi. org/IO.IO80/14708470802303082.]

Ibarraran, A., D. Lasagabaster \& J. M. Sierra (2008) «Multilingualism and language attitudes: Local versus immigrant students' perceptions», Language Awareness, I7(4), p. 326-34I. [DOI: I0.1080/096584I0802I473II.]

IpIÑA, N., \& P. SAGASTA (20I7) «Teacher students' attitudes towards English in a multilingual context», International Review of Applied Linguistics in Language Teaching, 55(I), p. 6I-92. [DOI: https://doi.org/I0.I5I5/iral-20I7-0008.]

JuAN-Garau, M. (2020) «L'educació de l'alumnat amb llengües d'herència: una mirada actual i reptes de futur», Caplletra, 68, p. I77-I97. [DOI: 10.7203/ caplletra.68.16476.]

Lasagabaster, D. (2005) «Attitudes towards Basque, Spanish and English: An analysis of the most influential variables», Journal of Multilingual and Multicultural Development, 26(4), p. 296-316. [DOI: 10.1080/0I434630508669084.]

- (2017) «Integrating content and foreign language learning: What do CLIL students believe? ", Journal of Immersion and Content-Based Language Education, 5(I), p. 4-29. [DOI: I0.1075/jicb.5.I.orlas.]

Lasagabaster, D. \& P. Safont (2008) «Un análisis de las actitudes lingüísticas en dos comunidades bilingües», in C. M. Bretones et al., Applied Linguistics Now: Understanding Language and Mind, Proceedings of the XXVI AESLA Conference, Almeria, Universidad de Almería, p. I83-196.

Lasagabaster, D. \& Y. Ruiz De Zarobe (20IO) CLIL in Spain: Implementation, results and teacher training, Newcastle upon Tyne, Cambridge Scholars Publishing. 
Irene Guzmán-Alcón \& Laura Portolés In-service teachers' language attitudes in the Valencian educational system: the effect of the school language programme and the L1

Lasagabaster, D \& A. Huguet, eds. (2007) Multilingualism in European bilingual contexts: language use and attitudes, Clevedon, Multilingual Matters.

Leonet, O., J. Cenoz \& D. Gorter (20I7) «Challenging Minority Language Isolation Translanguaging in a Trilingual School in the Basque Country», Journal of Language, Identity \& Education, I6 (4), p. 216-227. [DOI: I0.1080/I5348458.2017.I32828I.]

Liyanage, I. \& W. TAO (2020) «Preparation of Teachers and Multilingual Education: Ethical, Just, and Student-Focussed Practices», in W. Tao \& I. Liyanage (eds.), Multilingual Education Yearbook 2020, Suïssa, Springer, p. I-22. [DOI: IO.IOO7/978-3-03O-4I2II-I_I.]

Loredo Gutiérrez, L. Fernández Salgado, I. Suárez Fernández \& H. Casares BERG (2007) «Language use and language attitudes in Galicia», in D. Lasagabaster \& A. Huguet (eds.), Multilingualism in European Bilingual Contexts: Language Use and attitudes, Clevedon, Multilingual Matters, p. 40-64.

Madariaga, J. M., A. Huguet \& J. Janés (20i6) «Language attitudes in Catalan multilingual classrooms: educational implications", Language and Intercultural Communication, I6(2), p. 216-234.

Martí, O. (2020) «Tractament integrat de llengua i contingut: Quina llengua? Com s'integra? Per a què?», Caplletra, 68, p. 219-242. [DOI: I0.7203/caplletra.68.16478.]

Moratinos-Johnston, S., L. Ballester-Brage, M. Juan-Garau \& J. SalazarNoguera (2019) "Attitudes and motivation in English language learning amongst multilingual university students in the Balearic Islands: the effect of the L1 and other influential variables», Journal of Multilingual and Multicultural Development, 40(4), p. 475-490. [DOI: Io.IO80/oI434632.20I8.I53IOI2.]

Newman, M., M. Trenchs-Parera \& S. NG (2008) «Normalizing bilingualism: The effects of the Catalonian linguistic normalization policy one generation after», Journal of Sociolinguistics, I2(3), p. 306-333. [DOI: IO.IIII/j.I467984I.2008.00369.x.]

Nightingale, R. (2012) Bridging the gap between the internal and the external: The effect of sociocultural factors in adolescent learners' attitudes towards English, Alemanya, LAP Lambert Academic Publishing.

- (2016) The effect of out-of-school media contact on language attitudes in multilingual adolescents: A complex psychosociolinguistic system, Castelló, Universitat Jaume I.

Otwinowska, A. (20I7). "English teachers' language awareness: Away with the monolingual bias?" Language Awareness, 26(4), p. 304-324. [DOI: I0.1080/09658416.2017.1409752.]

O’rourke, B. \& F. Ramallo (2015) «Neofalantes as an active minority: Understanding language practices and motivations for change amongst new speakers of 
Irene Guzmán-Alcón \& Laura Portolés

In-service teachers' language attitudes in the Valencian educational system:

the effect of the school language programme and the L1

Galician", International Journal of the Sociology of Language, 231, p. I47-165.

[DOI: I0.1515/ijsl-20I4-0036.]

PortolÉs, L. (20I4) «Analysing prospective teachers' attitudes towards three languages in two different sociolinguistic and educational settings», in A. Otwinowska \& G. DeAngelis (eds.), Teaching and learningin multilingual contexts: sociolinguistic and educational perspectives, Clevedon, Multilingual Matters, p. 50-75.

- (2015) Multilingualism and very young learners. An analysis of pragmatic awareness and language attitudes, Boston, De Gruyter. [DOI: I0.1515/9781501500022.]

- (2020) «El multilingüisme a l'escola: tendències educatives i nous reptes», Caplletra, 68, p. I25-I47. [DOI: 10.7203/caplletra.68.I6474.]

Portolés, L. \& O. Martí (2020) «Teachers' beliefs about multilingual pedagogies and the role of initial training», International Journal of Multilingualism, I7(2), p. 248-264-I7. [DOI: 10.1080/I4790718.2018.1515206.]

SAFONT, P. (2007) «Language use and language attitudes in the Valencian community», in D. Lasagabaster \& A. Huguet (eds.), Multilingualism in European Bilingual Contexts: Language Use and attitudes, Clevedon, Multilingual Matters, p. 90-II6. - (20I5) «The promotion of multilingualism in a Catalan-speaking area. Familial challenges in the Valencian Community", in U. Jessner \& C. Kramsch (eds.) The Multilingual Challenge. Cross-Disciplinary Perspectives, Boston, de Gruyter, p. 39-59. [DOI: 10.1515/9781614512165-004.]

SARNOFF, I. (1970) «Social attitudes and the resolution of motivational conflict», in M. Jahoda \& N. Warren (eds.), Attitudes, Harmondsworth, Penguin, p. 27I-282.

\section{APPENDIX I}

We would like you to help us answer the following questions. This is not a test, so there are no right or wrong answers. The questionnaire is anonymous and data will be treated in the strictest confidence. We are interested in personal opinions, so please respond sincerely as this is the only way to guarantee the success of this study. Thank you very much for your participation.

Age [ ] ]

Sex (F: Female / H: Male) [ ]

L1 (C: Catalan-Valencian / S: Spanish / E: English) [ ] 
Here are some statements about the languages indicated above. Please say whether you agree or disagree with these statements. There are no correct or incorrect answers. Answer one of the following options using a scale from I to 5

$\mathrm{I}=$ totally disagree

$2=$ disagree

$3=$ neither agree nor disagree

$4=$ agree

$5=$ strongly agree

\section{About Catalan Language}

I. I like to listen to Catalan language

$[\mathrm{I}][2][3][4][5]$

2. Catalan must be taught in all the schools in the Valencian Community

$[\mathrm{I}][2][3][4][5]$

3. I like to speak Catalan

$[\mathrm{I}][2][3][4][5]$

4. Catalan is an easy language to learn

$[\mathrm{I}][2][3][4][5]$

5. You cannot learn other languages more useful than Catalan $[\mathrm{I}][2][3][4][5]$

6. I prefer Catalan as a vehicle language at school

$[\mathrm{I}][2][3][4][5]$

7. Learning Catalan enriches my cultural background

$[\mathrm{I}][2][3][4][5]$

8. I would not mind marrying a person who only spoke Catalan

$[\mathrm{I}][2][3][4][5]$

9. It is worth learning Catalan

Io. If I had children, I would like them to speak Catalan

$[\mathrm{I}][2][3][4][5]$

$[\mathrm{I}][2][3][4][5]$

\section{About Spanish Language}

I. I like to listen to the Spanish language

$[\mathrm{I}][2][3][4][5]$

2. Spanish must be taught to all the schools in the Valencian Community

$[\mathrm{I}][2][3][4][5]$

3. I like to speak Spanish

$[\mathrm{I}][2][3][4][5]$

4. Spanish is an easy language to learn

$[\mathrm{I}][2][3][4][5]$

5. You cannot learn other languages more useful than Spanish [I][2][3][4][5]

6. I prefer Spanish as a vehicle language in school

$[\mathrm{I}][2][3][4][5]$

7. Learning Spanish enriches my cultural background

$[\mathrm{I}][2][3][4][5]$

8. I would not mind marrying a person who only spoke Spanish

[I][2][3][4][5]

9. It is worth learning Spanish

$[\mathrm{I}][2][3][4][5]$

Io. If I had children I would like them to speak Spanish (apart from others)

$[\mathrm{I}][2][3][4][5]$ 
Irene GuZmán-Alcón \& Laura Portolés

In-service teachers' language attitudes in the Valencian educational system:

the effect of the school language programme and the L1

\section{About English Language}

I. I like to listen to the English language

$[\mathrm{I}][2][3][4][5]$

2. English must be taught to all the schools in the Valencian Community

3. I like to speak English [I][2][3][4][5]

$[\mathrm{I}][2][3][4][5]$

4. English is an easy language to learn

[I] [2][3][4][5]

5. You cannot learn other languages more useful than English

6. I prefer English as a vehicle language in school

$[\mathrm{I}][2][3][4][5]$

[I][2][3][4][5]

7. Learning English enriches my cultural background

$[\mathrm{I}][2][3][4][5]$

8. I would not mind marrying a person who only spoke English

$[\mathrm{I}][2][3][4][5]$

9. It's worth learning English

$[\mathrm{I}][2][3][4][5]$

IO. If I had children I would like them to speak English (apart from others)

$[\mathrm{I}][2][3][4][5]$

\section{APPENDIX II}

Semi-structured oral interviews

I. Do you allow your students to use another language in class? If so, what is the purpose?

2. Is multilingual education important in your school?

3. Are you more comfortable when you speak English, Catalan or Spanish? 